\title{
The Ethical Implications of Plagiarism and Ghostwriting in an Open Society
}

\author{
Patricia I. Fusch \\ Walden University \\ Lawrence R. Ness \\ Walden University \\ Janet M. Booker \\ Walden University \\ Gene E. Fusch \\ Walden University
}

Plagiarism is the theft of intellectual property. Plagiarism has been a problem in academic settings and appears to be on the increase, now moving into areas including the medical and scientific fields as well as industry, manufacturing, military, and legal briefs. The ethical implications can have serious consequences for organizations, individuals, and society, resulting in harm being done to others in favor of expediency. In this scholarly essay, the authors explore and discuss the ethical implications of plagiarism and the increase of ghostwriting in a free society through the writings of Kant, Popper, Kostenbaum, Plato, Whedbee, and others. The conclusion is that the act of stealing is not the true crime; rather, it is the act of deception that inflicts moral harm on all parties by damaging the reputation of self and others, insulting others' intelligence, and harming the integrity of all. The intended audience is students in their first year of a doctoral program.

Keywords: plagiarism, ghostwriting, ethics, ethical organizational leadership

\section{Introduction}

At the turn of the 21st century, plagiarism seemed to be more in the forefront of the media and has included issues from students copying assignments off the Internet to office theft of ideas and industrial espionage. While plagiarism has been a problem for some time (Mehrnoush \& Lashkarian, 2015) and appears to be on the increase, this challenge is now moving into areas previously perceived as unlikely to be affected. This increase in the spread of plagiarism has created new challenges for organizational leaders to limit risks and liabilities while resolving ethical dilemmas. Ethical implications can have serious consequences for organizations, individuals, and society as well, most notably in the scientific, national security, military, and medical fields, resulting in harm being done to others in favor of expediency (Whedbee, 2008). At the educational microlevel, plagiarism impacts the student. Justifications often given by perpetrators include time constraints, pressure for grade point averages (Dias \& Bastos, 2014), publish-or-perish requirements (Mohammed et al., 2015), and the ease of electronic sources as well as technological methods that utilize easy means of stealing (Bellack, 2004). 
In a larger context, plagiarism as deceptive communication affects all. Plagiarism and its detection and aftermath can be disruptive to an organization's performance. A leader's responsibility to the organization, as well as involved stakeholders, is to adapt and subsequently focus on resolving challenges and facilitating a return to business as usual (Deitchman, 2013). Good judgment calls are the same in these situations as well as the mundane.

Leaders are paid to recognize challenge situations and act upon them, to ensure that the organization's reputation survives. The leadership response to such a challenge may be the difference between organizational survival and inevitable demise (Cader \& Leatherman, 2011). Organizational leaders are now called upon to successfully cope with the challenge of plagiarism on the part of organizational employees, whether ignored or acknowledged. The responsibility of organizational leaders to address plagiarism speaks to the perceptions of community stakeholders and how they see the firm as tackling unethical behaviors on the part of employees. A failure to acknowledge and root out plagiarism can have an impact on the public image of the company and may result in long term financial and profitability decline despite any rigorous marketing or public relations campaigns. Moreover, the ethical implications should concern a society and community where dishonesty is perceived as realistic and unproblematic at best, and sanctions are light and rarely applied (S. Stern \& Lemmens, 2011).

\section{Examples of Plagiarism}

Kiehl (2006) developed the ABCDE model for ethical decision making. In an ironic case study of three nursing students caught plagiarizing another's work for an ethics research paper, the author addressed the need for clear policies regarding plagiarism, noting that the ethical implications for the medical field are serious and possibly life threatening in years to come. In a further case study of a military student caught cheating, Kiehl discussed another example of educational plagiarism by a divorced father with custody of two children who is soon to be deployed overseas as well as enter graduate school and was discovered to be copying another's work and presenting it as his own. The lack of personal integrity further translates to other actions of military personnel regarding how troops behave during deployment when fulfilling their duties and in their relationships with civilians. Integrity is one of the military's most important values along with courage, respect, and loyalty (U.S. Army, 2016).

Finally, plagiarism may be given a pass by those persons whom society has given primary responsibility to address the problem. Kock and Davison (2003) discussed plagiarism in the information systems research community, specifically the ethical dilemmas for editors of peerreviewed research publications in medicine and science. The authors addressed the issue of editors who are under time constraints to publish relevant, groundbreaking work. Furthermore, these ethical dilemmas are particularly problematic for editors and reviewers whose responsibilities include ensuring submissions meet journal standards; they do not review for plagiarism (Kock \& Davison, 2003).

\section{Whedbee and the Ongoing Discussion of How Plagiarism Is Defined}

Literary theft is a synonym for plagiarism (Whedbee, 2008). The prevalence of plagiarism is growing outside the field of literature into medicine, science, engineering, and into the field of fiction (Stretton, 2014). This type appears to be on the increase including examples from well-known popular authors such as Doris Kearns Goodwin, Stephen E. Ambrose, and former Vice President Joe Biden. It is not the act of stealing that is reprehensible, but it is the act of deception that is the true crime. The original harm is compounded through the actions of others as readers of the work- 
actions they may not have initiated had they known the work was stolen. The ethical implications of plagiarism on self, aggrieved party, intended audience, and the community as a whole is the moral harm inflicted on all parties which damages the reputation of self and the others, insults others intelligence, and harms the integrity of all (A. M. Stern, Casadevall, Steen, \& Fang, 2014).

Whedbee (2008) gave a three-point definition of the elements that comprise plagiarism including copying an entire body of work, copying portions of a body of work, and paraphrasing another's work without proper citation. Examples of these definitions can include student's wholesale cut-and-paste strategies, as well as presidential speeches, ghostwriters, and the issue of time constraints, audience expectations, and the issue of genuine knowledge attribution (Bassendowski \& Salgado, 2005; Kiehl, 2006; Zheng \& Cheng, 2015). Whedbee (2008) used the case of Kaavya Viswanathan as a strong jumping-off point for a discussion of plagiarism and its moral and ethical implications and impacts. Viswanathan was 19-year-old new talent who had written a novel that was shown to be largely duplicated from novelist Megan McCafferty's work. Moreover, the author has detailed these ethical considerations and taken the discussion beyond the usual plagiarist-originating author viewpoint and drawn readers into an analysis of the community as third-party participant and victim. Some fail to provide an accurate portrayal of what plagiarism consists of, usually focusing on a general definition of plagiarism as the theft of another's work.

Whedbee (2008) neatly and concisely set this misconception to rest. One might fault the author for taking the easy way out in her discussion by focusing on the usual suspects, that is, Goodwin, Ambrose, and Biden. Certainly, a case can be made that the author may be trying to reach a general audience and knows that many people have heard of these stories, thereby sacrificing a more detailed analysis for easy clarity and responsiveness of her audience. This is problematic in that plagiarism has more serious consequence in many fields (Masic, 2012).

Presenting a well-known and extensively covered case of plagiarism in the field of literature is a good starting point for a discussion amongst readers. The facts of the case are generally known amongst participants and the moral, legal, and ethical implications have been written and discussed already in the public realm and, therefore, the ideas behind them are generally understood by most. A general case study is, however, just that. It is a beginning to a serious discussion of the definition of plagiarism and its impact on society as a whole. One could better serve the discussion by beginning at the beginning, as it were, and continuing the discussion into the more serious impact of plagiarism and dishonesty in fields other than literature and journalism. The results of dishonesty in the classroom, lab, combat unit, and workplace have even more serious consequences for everyone because of the impact on society and individuals (Masic, 2012).

\section{Ghostwriting}

Ghostwriting is defined as writing in the name of another for publication under another's name (Landers, 2008). It is more commonly known and used by speech writers for presidents and political leaders, particularly when major governmental policies are presented to the general public such as when major legislation has passed or a significant congressional bill has been signed. Furthermore, governmental leaders have used ghostwriters to write speeches after significant events have occurred in the public sphere, such as major disasters or the declaration of war. While the intent is to present a best clarified presentation of a leader's thoughts, some postulate that it has instead led to rely on others to make important points that are better left to leaders to explain (Landers, 2008). 
The practice of ghostwriting and speeches is changing. Landers (2008), reporting for the Wall Street Journal, wrote that ghostwriting for presidential speeches and books has been a long-known practice and appears to be generally accepted. Although American presidents hid their speechwriters from the general public and media, it appears that ghostwriting is commonplace and considered to be ethically sound. Relying on anecdotal evidence and history books, the writer noted that reliance on ghostwriting has morphed from speeches to policy-making. This is problematic at best and disturbing at worst because of undue influence on major decisions by those who are not held accountable for their actions. Landers wrote that presidential speeches are now important as a means of public persuasion, as well as a method to enforce discipline and decision making amongst the ranks of the executive office to keep the minions on message.

Furthermore, ghostwriting has moved out of politics and executive offices and into the medical and scientific fields; sometimes the contribution is limited to getting a manuscript ready for publication in terms of grammar, punctuation, and other formatting issues (Das \& Das, 2014; S. Stern \& Lemmens, 2011; Stretton, 2014). Some well-known journals are taking the unprecedented step of educating their communities about the pitfalls of what constitutes unethical ghostwriting (Roberts, 2009). Mathews (2005) discussed that ghostwriters are prevalent in the writing of research articles for peer-reviewed journals. That may not appear to be problematic on the surface, but ghostwriters are receiving help from pharmaceutical companies as part of a marketing campaign for their products. Many articles that appear in scientific journals are actually written by ghostwriters paid by pharmaceutical firms (Mathews, 2005). Researchers, doctors, and patients are receiving biased information; most medical and scientific publications are now requiring academics to disclose the use of ghostwriters and sponsoring companies. It is only by disclosing ghostwriting that readers can weigh its influence and determine the extent of any unethical behavior (Bosch \& Ross, 2012; Dawes, 2007; Zheng \& Cheng, 2015).

Riley and Brown (1996) reviewed results from 180 questionnaires returned by undergraduate students majoring in business courses at a southwestern university. Using a regression analysis formula in a quantitative analysis of the results, the study results demonstrated that most people recognize that ghostwriters are used in speeches, autobiographical books, and the like. While the respondents indicated understanding that under certain circumstances ghostwriting could be acceptable, ghostwriting should also be acknowledged and attributed to by authors. Moreover, respondents were unanimous in stating that the responsibility for the material rested with the author, not the ghostwriter.

In a side note to the discussion of the findings, Riley and Brown (1996) indicated that undergraduate respondents to be universal in their ethical standards of ghostwriting when it came to oneself. The respondents specified that they did not intend to nor had they in the past used ghostwriters for their own work. It can be stated, however, that ghostwriting for students can be on a slippery slope towards plagiarism. The ethics of ghostwriting elicits a series of questions from observers.

1. What is the communicator's intent?

2. What is the audience's degree of awareness?

3. What extent does the ghostwriter improve the communicator's image?

4. (To) what extent does the ghostwriter disguise or distort the communicator's true image?

5 . What is the communicator's role?

6. What are the surrounding circumstances?

7. How active are communicators in the actual writing?

8. Does the communicator accept responsibility for the message presented? 
Prudent readers should apply these questions to any work that is either disclosed as ghostwritten or works that the reader suspects may be ghostwritten. The intent of the questions is to elicit the influence and impact of the ghostwriter on the material presented, including political views, bias, and intentional or unintentional deletion of critical material (Johannesen, Valde, \& Whedbee, 2008).

\section{Ethical Implications for All Organizations}

After the end of World War II, traditional leadership and management models presumed homogenous workplaces and subsequent organizational standards, which may not be applicable today. Leaders in contemporary multicultural organizations now must manage in an environment where there are no common definitions of efficient outcome or effectiveness. This makes it imperative that organizations have a common set of standards of ethics and integrity (Bishop, 2013) as well as communicating them to the workforce and the surrounding community of stakeholders (Resick, Hargis, Shao, \& Dust, 2013). Integrity is a component of what determines character, or a pattern of behavior and actions regardless of circumstances (Johannesen et al., 2008). Furthermore, integrity involves reliability, consistency, and keeping promises. It is acting with courage by being true to personal ethics; all flow from integrity, including honesty, openness, courage, and fairness, to name a few.

Johannesen et al. (2008) noted that much of ethical communication is situational and tailored to roles, standards, degrees of urgency and awareness, as well as goals and values of both communicator and audience. While the nature of situational ethics is problematic due to a tendency of selfish justification on the part of the speaker, most, if not all, make this judgement call at some time (Johannesen et al., 2008).

\section{Sanctions}

Sanctions for plagiarism have long been ignored or lightly addressed, particularly in undergraduate education. Abilock (2006), a college librarian who wrote a code of ethics for an employer, presented a case study of undergraduate plagiarism of a scientific study. A senior at the college was caught plagiarizing a scientific article and presenting it as her own work a short time before graduation. In response, the college lightly reprimanded the student and allowed her to graduate. After writing about student justifications for plagiarism, the author went on to address the need for an organization-wide culture of ethical behavior; the need for agreement and acceptance by faculty, staff, and students; and the need for stronger sanctions against those caught plagiarizing.

Faculty members who expect students to cite all sources in their work also tend to take a more formal approach to plagiarism by reporting it to senior leadership (Singh \& Bennington, 2012), particularly if the reporting process is easy to implement (Holbeck et al., 2015).

Moreover, educating students about what constitutes plagiarism is a forward-thinking process recommended by Wheeler and Anderson (2010) regarding the English-as-a-second-language student submissions, as well as by Evering and Moorman (2012). Some plagiarism is the result of a lack of knowledge about how to properly cite the words of others (Belter \& Du Pre, 2009; Kier, 2014). Liu, Lo, and Wang (2013) pointed out that cultural influence may dictate evidence of plagiarism. Confucian tradition emphasizes memorization and repetition rather than independent thought (Chien, 2014). 
In an address at Ohio State University, Dr. Lana Rakow discussed and advocated the need for a communication ethical ground rules for individuals to guide relationships between persons, cultures, organizations, and countries (Johannesen et al., 2008). Some of these ethics are inclusiveness, participation, and reciprocity. The goal is to foster healthy, egalitarian, and respectful dialogue with others. Dr. Rakow developed the following three ethical communication ground rules: (a) promptness, (b) distraction avoidance, and (c) openness. Promptness refers to addressing problems in a timely manner, yet being sensitive to issues of feelings. Distraction avoidance involves the refusal to be sidetracked by peripheral issues as well as making it a top priority to communicate ethically with others. Openness is about receiving communication of more than one interpretation or perspective. It is what Dr. Rakow referred to as inclusiveness or acknowledging that there are many paths to perceptions regarding truth.

Courage to act with integrity is perhaps the primary emotion in a leader. It is the ability to reason independent of conflicting opinions, the skill to generate inner data. Courageous leaders seize the initiative and act with integrity (Koestenbaum, 2002) by understanding the consequences of actions. In this respect, plagiarism is one action that affects the organization, the individual, stakeholders, and the general public. In its larger context, plagiarism as deceptive communication affects us all. Indeed, plagiarism brings some of the old as well as new challenges to any organization. The effective leader models ethical behavior through intolerance of plagiarism and deceptive communication within the workplace, thereby setting the standards others are expected to follow.

\section{Conclusion}

The authors of this article work with doctoral students to identify issues in their writing, primarily because they find that instances of plagiarism most often are merely a manifestation of writing challenges. Students who are willing to learn can then adjust by finding their academic voice and writing in their own words. A small percentage of students have no interest in learning to write and will copy and paste the words of others regardless of what help is offered. How these students address their personal mistakes regarding plagiarizing the words of others can determine their ultimate success in academia. These same few students usually do not succeed in their doctoral programs. What remains to be seen is their potential impact in the marketplace during transition to employment in the medical, scientific, legal, and in other fields where plagiarism exists.

One's personal ethical core most likely remains constant, although it can morph into new manifestations. It is important to recognize that some feel that beliefs are solid and everlasting; however, as humans, we are constantly experiencing new things in life and our beliefs change with our experience, most likely becoming deeper rather than changing altogether (Popper, 1963). Beliefs as theory can be tested and then falsified or deemed closer to verisimilitude, but can never be verified as the truth (Popper, 1959, 1963). Observations in the sense of statements regarding the truth are one of the ways we manifest our world view-our reality and what we believe to be true. We do see what we expect to see and not what is actually there; in some ways this is much like what Plato described in the allegory of the cave from The Republic. The shadows on the wall are our representation of reality, our beliefs about what is true, regardless of their verisimilitude (Henderson, Oakes, \& Smith, 2009). Immanuel Kant felt that the human viewpoint shapes our world.

Popper (1963) made it clear that it is important that, as individuals and as a people, we learn from our mistakes. Upon reflection, the authors of this article have found themselves thinking back upon their years of employment and recognizing both positive and negative ethical choices made by the students they have known and mentored. This reflection has taught them that others are always 
watching to see if actions mirror words, that a weakness in one area can undermine the entire structure, that hypocrisy can be more destructive than holding others accountable, and that process is not necessarily as important as ethical motivation. In the end, plagiarism as deceptive communication affects us all.

\section{References}

Abilock, D. (2006). Is your ethics policy a quick fix or a civic outcome? Knowledge Quest, 34, 7-9. Retrieved from http://knowledgequest.aasl.org/

Bassendowski, S. L., \& Salgado, A. J. (2005). Is plagiarism creating an opportunity for the development of new assessment strategies? International Journal of Nursing Education Scholarship, 2, 3-13. doi:10.2202/1548-923X.1098

Bellack, J. P. (2004). Why plagiarism matters. Journal of Nursing Education, 43, 527-528. Retrieved from http://www.journalofnursingeducation.com/SHOWABST.asp?thing=35175

Belter, R. W., \& Du Pre, A. (2009). A strategy to reduce plagiarism in an undergraduate course. Teaching of Psychology, 36, 257-261. doi:10.1080/00986280903173165

Bishop, W. H. (2013). The role of ethics in 21st century organizations. Journal of Business Ethics, 118, 635-637. doi:10.1007/s10551-013-1618-1

Bosch, X., \& Ross, J. S. (2012). Ghostwriting: Research misconduct, plagiarism, or fool's gold? The American Journal of Medicine, 125, 324-326. doi:10.1016/j.amjmed.2011.07.015

Cader, H. A., \& Leatherman, J. C. (2011). Small business survival and sample selection bias. Small Business Economics, 37, 155-165. doi:10.1007/s11187-009-9240-4

Chien, S. C. (2014). Cultural constructions of plagiarism in student writing: Teachers' perceptions and responses. Research in the Teaching of English, 49, 120-140. Retrieved from http://www.ncte.org/journals/rte

Das, N., \& Das, S. (2014). Hiring a professional medical writer: Is it equivalent to ghostwriting? Biochemia Medica, 24, 19-24. doi:10.11613/BM.2014.004

Dawes, K. (2007). Personal views: Ghost writers need to be more visible. British Medical Journal, 334, 208. doi:10.1136/bmj.39104.595463.94

Deitchman, S. (2013). Enhancing crisis leadership in public health emergencies. Disaster Medicine and Public Health Preparedness, 7, 534-540. doi:10.1017/dmp.2013.81

Dias, P. C., \& Bastos, A. S. C. (2014). Plagiarism phenomenon in European countries: Results from GENIUS project. Procedia-Social and Behavioral Sciences, 116, 2526-2531. doi:10.1016/j.sbspro.2014.01.605

Evering, L. C., \& Moorman, G. (2012). Rethinking plagiarism in the digital age. Journal of Adolescent \& Adult Literacy, 56, 35-44. doi:10.1002/JAAL.00100

Henderson, M. C., Oakes, G., \& Smith, M. (2009). What Plato knew about Enron. Journal of Business Ethics, 86, 463-471. doi:10.1007/s10551-008-9858-1

Holbeck, R., Greenberger, S., Cooper, L., Steele, J., Palenque, S. M., \& Koukoudeas, S. (2015). Reporting plagiarism in the online classroom. Journal of Online Learning and Teaching, 11, 202-209. Retrieved from http://jolt.merlot.org/Vol11no2/Holbeck_0615

Johannesen, R. L., Valde, K. S., \& Whedbee, K. E. (2008). Ethics in human communication (6th ed.). Long Grove, IL: Waveland Press. 
Kiehl, E. M. (2006). Using an ethical decision-making model to determine consequences for student plagiarism. Faculty Forum, 45, 199-203. Retrieved from

http://www.journalofnursingeducation.com

Kier, C. A. (2014). How well do Canadian distance education students understand plagiarism? International Review of Research in Open and Distance Learning, 15(1), 227-248. Retrieved http://www.irrodl.org/index.php/irrodl/article/view/1684

Kock, N., \& Davison, R. (2003). Dealing with plagiarism in the information systems research community: A look at factors that drive plagiarism and ways to address them. MIS Quarterly, 27, 511-532. Retrieved from http://www.misq.org/

Koestenbaum, P. (2002). Leadership, the inner side of greatness: A philosophy for leaders (Rev. ed.). San Francisco, CA: Jossey-Bass.

Landers, R. K. (2008, April 12). Books: Presidential words; in a speechifying season, a look at how the writer's job has changed. Wall Street Journal (Eastern edition), p. W8. Retrieved from http://online.wsj.com/

Liu, G. Z., Lo, H. Y., \& Wang, H. C. (2013). Design and usability testing of a learning and plagiarism avoidance tutorial system for paraphrasing and citing in English: A case study. Computers \& Education, 69, 1-14. doi:10.1016/j.compedu.2014.06.007

Masic, I. (2012). Plagiarism in scientific publishing. Acta Informatica Medica, 4, 208-213. doi:10.5455/aim.2012.20.208-2132

Mathews, A. W. (2005, December 13). Ghost story: At medical journals, writer paid by industry play big roles; Articles appear under name of academic researchers, but they often get help; $J$ \& $J$ receives a positive 'spin'. Wall Street Journal (Eastern edition), p. A1. Retrieved from http://online.wsj.com/

Mehrnoush, M. M., \& Lashkarian, A. A. (2015). The university students' perceptions of plagiarism in ESP/EAP courses. Modern Journal of Language Teaching Methods, 5, 281-285. Retrieved from http://mjltm.org/

Mohammed, R. A. A., Shaaban, O. M., Mahran, D. G., Attellawy, H, N., Makhlof, A., \& Abdulkader, A. (2015). Plagiarism in medical scientific research. Journal of Taibah University Medical Sciences, 10, 6-11. doi:10.1016/j.jtumed.2015.01.007

Popper, K. R. (1959). The logic of scientific discovery. London, United Kingdom: Hutchinson.

Popper, K. R. (1963). Conjectures and refutations: The growth of scientific knowledge. New York, NY: Harper \& Row.

Resick, C. J., Hargis, M. B., Shao, P., \& Dust, S. B. (2013). Ethical leadership, moral equity judgments, and discretionary workplace behavior. Human Relations, 66, 951-972. doi:10.1177/0018726713481633

Resnick, B. (2014). Publishing a DNP capstone: After the where, what and how. The ethics and process of manuscript submission. Geriatric Nursing, 35, 91-92. doi:10.1016/j.gerinurse.2013.11.009

Riley, L. A., \& Brown, S. C. (1996). Crafting a public image: An empirical study of the ethics of ghostwriting. Journal of Business Ethics, 15, 711-720. doi:10.1007/BF00381736

Roberts, J. (2009). An author's guide to publication ethics: A review of emerging standards in biomedical journals. Headache, 49, 579-589. Retrieved from http://www.headachejournal.org

Singh, H., \& Bennington, A. J. (2012). Faculty on the frontline: Predicting faculty intentions to address college student plagiarism. Academy of Educational Leadership Journal, 16, 115- 
128. Retrieved from http://www.alliedacademies.org/academy-of-educational-leadershipjournal/

Stern, A. M., Casadevall, A., Steen, R. G., \& Fang, F. C. (2014). Financial costs and personal consequences of research misconduct resulting in retracted publications. eLife, 3, e02956. doi:10.7554/eLife.02956

Stern, S., \& Lemmens, T. (2011). Legal remedies for medical ghostwriting: Imposing fraud liability on guest authors of ghostwritten articles. PLoS Medicine, 8, e1001070. doi:10.1371/journal.pmed.1001070

Stretton, S. (2014). Systematic review on the primary and secondary reporting of the prevalence of ghostwriting in the medical literature. BMJ Open, 4, 1-11. doi:10.1136/bmjopen-2013-004777

Tanase, B. G. (2014). Give ghosts a chance: Why federal courts should cease sanctioning every legal ghostwriter. Georgia Law Review, 48, 661-690. Retrieved from http://georgialawreview.org

U.S. Army. (2016). The Army values. Retrieved from https://www.army.mil/values/

Whedbee, K. E. (2008). In other's words: Plagiarism as deceptive communication. In R. L. Singh, K. S. Valde, \& K. E. Whedbee (Eds.), Ethics in human communication (6th ed., pp. 283-292). Long Grove, IL: Waveland.

Wheeler, D., \& Anderson, D. (2010). Dealing with plagiarism in a complex information society. Education, Business and Society: Contemporary Middle Eastern Issues, 3, 166-177. doi:10.1108/17537981011070082

Zheng, S., \& Cheng, J. (2015). Academic ghostwriting and international students. Young Scholars in Writing, 12, 124-133. Retrieved from https://arc.lib.montana.edu/ojs/index.php/YoungScholars-In-Writing/article/view/4

The Journal of Social Change, sponsored by Walden University, welcomes manuscripts focusing on interdisciplinary research in social change that improves the human condition and moves people, groups, organizations, cultures, and society toward a more positive future.

Walden University Publishing: http://www.publishing.waldenu.edu 